\title{
Photodynamic Therapy In Vitro
}

4 Mona Doshi, ${ }^{1}$ Alicja Copik, ${ }^{2}$ Andre J. Gesquiere ${ }^{1, *}$

1. NanoScience Technology Center, Department of Chemistry, Department of Materials Science and Engineering, and CREOL, The College of Optics and Photonics, University of Central Florida, 12424 Research Parkway Suite 400, Orlando, FL 32826, USA

2. Burnett School of Biomedical Sciences, College of Medicine, University of Central Florida, 6900 Lake Nona Boulevard, Orlando, FL 32827, USA

11

* To whom correspondence should be addressed. E-mail: andre@ ucf.edu (A. J. Gesquiere)

14 ABSTRACT

15 Conducting polymer nanoparticles (CPNPs), composed of the conducting polymer poly[2methoxy-5-(2-ethylhexyl-oxy)-p-phenylenevinylene] (MEH-PPV) were studied for applications

17 in biophotonics and therapeutics. The extent of cellular uptake, cytotoxicity, and effectiveness of 18 these nanoparticles in photodynamic therapy (PDT) was investigated for four cell lines, namely

19 TE-71, MDA-MB-231, A549 and OVCAR3. Confocal fluorescence imaging and flow cytometry

20 show that CPNPs are taken up only in limited quantities by TE-71, while they are taken up

21 extensively by the cancer cell lines. The uptake among the cancer cell lines was observed to vary 22 with cell line, with CPNPs uptake increasing from MDA-MB-231 to A549 to OVCAR3.

23 Fluorescence imaging experiments show that the CPNPs have high brightness and appear stable 
1 in the intracellular environment. No cytotoxicity of non-photoactivated CPNPs (in dark) was

2 observed from MTT assay. After completion of PDT, the quantitative data on cell viability

3 suggest that cell death scales across the cell lines with CPNP uptake, is light dose dependent, and

4 is complete for OVCAR3. In addition, for OVCAR3 apoptotic cell death is observed after PDT.

5 The reported work illustrates the potential of the intrinsically fluorescent and photoactivateable

6 CPNPs for application in biophotonics and therapeutics.

KEYWORDS : ROS, MEH-PPV, conducting polymer, triplets, PDT, aggregation

\section{Introduction}

11 Chemotherapy [1-5], surgery [6-8] and radiotherapy [9,10] are currently widely used in clinical

12 settings for treatment of cancer. Multimodal treatments such as chemotherapy combined with

13 immunotherapy [11,12] or with radiotherapy [13] are also used. Research on further treatment

14 development is ongoing. Surgery has recently seen improvements by the development of laser

15 surgery [14-18] and fluorescence imaging guided surgery [19,20]. Small molecules such as

16 doxorubicin [21-23] have been extensively studied, and others such as STAT3 inhibitors [24-26],

17 are currently under investigation. Nanocarrier versions of small molecule drugs and new

18 nanoparticle drugs are also under development with the aim to improve delivery and therapeutic

19 properties [27,28] In addition, photodynamic therapy (PDT) has been shown to be a promising

20 treatment scheme for cancer through clinical trials and preliminary application at treatment

21 centers [29-34].

22 In PDT a photosensitizing material is internalized by cancer cells, and subsequently these cells

23 are irradiated with light. The photosensitizer generates Reactive Oxygen Species (ROS) under 
1 exposure to light that can induce oxidative stress and subsequent structural damage in cancer

2 cells, potentially leading to cell death [35-39].

3 For normal cells, ROS are essential in the regulation of cell functions such as cell signaling and

4 apoptosis. ROS levels are kept in check under ordinary circumstances by intrinsic antioxidants

5 present in cells. Studies on formation of cancerous cells have shown that when ROS levels

6 increase to an extent where they can no longer be removed by the intrinsic antioxidants present

7 in cells, this condition can lead to cancer [40-43]. As such, cancer cells need elevated amounts of

8 ROS for proliferation, but at the same time cancer cells do not have sufficient antioxidants to

9 scavenge ROS. Thus even while cancer cells thrive with elevated ROS levels, they are also very

10 susceptible to externally stimulated elevation of ROS levels [44-47].

11 Developments in nanotechnology inspired photosensitizers have brought new developments to

12 PDT. Various inorganic nanoparticle photosensitizers such as quantum dots[48,49], gold

13 nanoparticles [50-52], magnetic nanoparticles [53,54], silica nanoparticles [55-58], and titanium

14 oxide nanoparticles [59] have been developed and studied. A few examples of organic

15 nanoparticle photosensitizers such as methacrylate polymer nanoparticles doped with verteporfin

16 as the photosensitizers and polymeric micelles of block copolymer poly(ethylene glycol)-co-

17 poly(D,L-lactic acid) (PEG-PLA) loaded with 5,10,15,20-tetrakis(mesohydroxyphenyl)porphyrin

18 (mTHPP) as the photosensitizer have been reported [60,61]. Liposomes doped with various

19 photosensitizers have been studied for application in PDT [62]. For instance, aminolevulinic acid

20 encapsulate liposomes were recently reported for PDT application [63]. Phthalocyanine

21 conjugated polypropylenimine dendrimers, and porphyrine phthalocyanine decorated dendrimers

$22[64,65]$ have also been reported. 
1 Recently, photosensitizer-doped conducting polymer nanoparticles have received attention as

2 potential photosensitizers for PDT. Photosensitizer doped conjugated polymer nanoparticles

3 were developed and characterized by Grimland et al. Singlet oxygen formation by

4 tetraphenylporphyrine (TPP) photosensitizer under one- and two-photon excitation was proven

5 by UV-vis spectroscopy, and DNA damage as proof-of-concept was shown by these authors.

6 [66]. Shen et al. concurrently proved the formation of singlet oxygen for tetraphenylporphyrine

7 (TPP) photosensitizer doped conjugated polymer nanoparticles by singlet oxygen

8 luminescence[67]. Zhang et al. more recently followed a similar nanoparticle design scheme

9 with meta-tetra-(hydroxyphenyl)-chlorin (m-THPC) as photosensitizer to produce ROS[68].

10 In this article, conducing polymer nanoparticles fabricated from the conducting polymer poly[2-

11 methoxy-5-(2-ethylhexyloxy)-1,4-phenylenevinylene] (MEH-PPV) were studied for application

12 in PDT. Photosensitization was found to be intrinsic to these conducting polymer nanoparticles

13 (CPNPs) without the use of photosensitizer dopants. These CPNPS were investigated in vitro for

14 their potential application in PDT for cancer treatment. The CPNPs show bright emission in vitro

15 that enables fluorescence imaging of internalized CPNPs. It was observed that these CPNPs have

16 a strong intrinsic bias towards the cancer cell lines studied here without surface modification.

17 The CPNPs were observed to be not intrinsically cytotoxic (no cytotoxicity observed in dark),

18 and show very promising PDT results. PDT was highly effective for lung and ovarian cancer-

19 derived cell lines at moderate intensities of visible light, without observation of phototoxicity.

\section{2. Materials and Methods}

22 2.1. Fabrication of NPs 
1 Poly[2-methoxy-5-(2-ethylhexyloxy)-1,4-phenylenevinylene] (MEH-PPV) with molecular

2 weight (average Mn) 150,000-250,000 g/mol was purchased from Sigma Aldrich and used

3 without any further purification. THF (tetrahydrofuran) Drisolv was purchased from EMD

4 Millipore. The CPNPs were fabricated following previously published protocol. [69-71]. In

5 short, $1 \mathrm{mg}$ MEH-PPV was dissolved in THF and was diluted to a $10^{-6} \mathrm{M}$ concentration. $1 \mathrm{ml}$ of

6 this solution of MEH-PPV in THF was quickly injected into $4 \mathrm{ml}$ of DI water under vigorous

7 stirring. Stirring was stopped immediately after injection of the polymer solution in water.

9 2.2. Characterization

$10 \quad$ 2.2.1. Dynamic light scattering

11 The size of the CPNPs was determined with a Precision Detector Dymanic Light Scattering 12 (PD2000DLS) machine. Data was analyzed using the Precision Deconvolve software.

$14 \quad$ 2.2.2. UV-visible spectroscopy

15 The absorption spectroscopy on the CPNPs suspension in water was completed in a $1 \mathrm{~cm}$ path

16 length quartz cuvette with an Agilent 8453 spectrophotometer using the Chemstation software.

$18 \quad 2.2 .3$. Fluorescence spectroscopy

19 The fluorescence spectroscopy on the CPNPs suspension in water was performed in a $1 \mathrm{~cm}$ path 20 length quartz cuvette with a Nanolog ${ }^{\mathrm{TM}}$ HoribaJobin Yvon fluorimeter. 
1 TE-71 (Mouse thymic epithelial cell line), MDA-MB-231 (Human breast cancer cell line), A549

2 (Human lung cancer cell line) and OVCAR3 (Ovarian tumor cell line) were purchased from

3 ATCC and grown in DMEM media supplemented with 10\% FBS in in humidified atmosphere of $495 \%$ air/ $5 \% \mathrm{CO}_{2}$ at $37^{\circ} \mathrm{C}$.

6 2.4. Incubation with CPNPs for fluorescence imaging

7 The TE 71, MDA-MB-231, A549 and OVCAR3 cell lines were grown in 96 well plates for 24

8 hours. Then the media was removed and after washing with PBS the cells were incubated with

9 CPNPs at following concentrations: $0 \mathrm{mg} / \mathrm{ml}$ (vehicle control), $0.4 \times 10^{-4} \mathrm{mg} / \mathrm{ml}, 2 \times 10^{-4} \mathrm{mg} / \mathrm{ml}$

10 and $3.6 \times 10^{-4} \mathrm{mg} / \mathrm{ml}$ in media. After 24 hours the CPNPs solution was removed and cells were

11 washed with PBS and harvested with trypsin. These were then plated in different $35 \mathrm{~mm}$ petri

12 dishes and allowed to grow for 24 hours again. Then the cells were fixed with $4 \%$

13 paraformaldehyde, stained with DAPI and suspended in PBS to image.

\subsection{Intrinsic cytotoxicity of CPNPs}

16 The cells were grown in 96 well plates and were incubated with $0.4 \times 10^{-4} \mathrm{mg} / \mathrm{ml}, 2 \times 10^{-4} \mathrm{mg} / \mathrm{ml}$

17 and 3.6x $10^{-4} \mathrm{mg} / \mathrm{ml}$ of CPNPs, together with the corresponding controls. Cells were incubated

18 with CPNPs for up to 24 hours. Cell viability was determined 0, 24, 48, 72 and 96 hours after

19 addition of CPNPs by MTT assay. For the 0 and 24 hour time point, MTT was added

20 immediately after adding CPNPs and 24 hours after addition of CPNPs, respectively. For the 48,

2172 and 96 hours readings, the CPNPs solution was removed after 24 hours and replaced with

22 regular media. MTT was then added at the corresponding time points. MTT was allowed to

23 incubate for 4 hours to allow formazan to form. Then the solubilization solution was added and 
1 after 6 hours the 96 well plates were read. The readings were taken at $570 \mathrm{~nm}$ on a Biotek

2 ELx800 absorbance microplate reader.

4 2.6. Photodynamic Therapy PDT

5 Cells were grown in 96-well plates for 24 hours. Then the cells were incubated with different

6 doses of CPNPs. After 24 hours the media was replaced with HBSS (Hank's Balanced Salt

7 Solution) and the 96 well plates with the cells were exposed to visible light by using a solar

8 simulator (Newport 67005 Oriel Instruments) and a UV filter (FSQ-GG400) to block the UV

9 light. Three light doses $\left(60 \mathrm{~J} / \mathrm{cm}^{2}, 120 \mathrm{~J} / \mathrm{cm}^{2}\right.$ and $\left.180 \mathrm{~J} / \mathrm{cm}^{2}\right)$ and three CPNP doses $\left(0.4 \times 10^{-4}\right.$

$10 \mathrm{mg} / \mathrm{ml}, 2 \times 10^{-4} \mathrm{mg} / \mathrm{ml}$ and $\left.3.6 \times 10^{-4} \mathrm{mg} / \mathrm{ml}\right)$ along with one control dose $(0 \mathrm{mg} / \mathrm{ml})$ were used for

11 PDT. For each light dose three post-PDT incubation periods (0 hours, 4 hours and 12 hours)

12 were evaluated. Then MTT was added to the 96 well plates immediately after PDT, and 4 and 12

13 hours post-PDT incubation. The experiment was performed 3 times $(n=3)$.

14

15

16

17

18

19

20

21

22

23

24

\subsection{Detection of ROS}

The A549 and OVCAR3 cells were incubated with $2 \times 10^{-4} \mathrm{mg} / \mathrm{ml} \mathrm{CPNPs.} \mathrm{After} 24$ hours the media was replaced with HBSS and the samples were exposed to a $180 \mathrm{~J} / \mathrm{cm}^{2}$ light. The CellROX green reagent was added to the media 1) immediately after the light treatment and 2) after 2 hours of post-PDT incubation. After 30 minutes the reagent was washed and the cells were fixed with $4 \%$ paraformaldehyde and stained with DAPI. The cells were kept in PBS for imaging. Three negative controls 1) No CPNPs and no light dose, 2) only light dose of 180 $\mathrm{J} / \mathrm{cm}^{2}$, and 3) only CPNPs dose of $2 \times 10^{-4} \mathrm{mg} / \mathrm{ml}$, and one positive control with $100 \mu \mathrm{M} \mathrm{H}_{2} \mathrm{O}_{2}$ were also performed. 
2 TE-71, MDA-MB-231, A549 and OVCAR3 at $1 \times 10^{6}$ cells/ml concentration were incubated

3 with $2 \times 10^{-4} \mathrm{mg} / \mathrm{ml}$ CPNPs for 24 hours. Then the cells were harvested, washed and fixed with

$44 \%$ paraformaldehyde, and flow cytometry was performed on these samples with a BD FACS

5 Canto II flow cytometer (BD Biosciences). The data were processed with FlowJo software

6 (FlowJO). The experiment was performed 2 times $(\mathrm{n}=2)$.

\subsection{Optical Microscopy}

9 2.9.1. Confocal Imaging for CPNP Uptake

10 The fixed cells were imaged by spinning disc confocal fluorescence microscope (Zeiss 11 Axioskop2) by using the 488nm wavelength from a Kr-Ar ion laser and FITC filters to detect the

12 fluorescence from CPNPs. The DAPI images were taken by excitation with mercury lamp and 13 DAPI filters. The CPNPs images and DAPI images were overlayed using ImageJ software. To 14 confirm that the CPNPs were inside the cells, images at every $0.3 \mu \mathrm{m}$ were taken along the $\mathrm{Z}$ 15 axis. A selection of these slices was used representing a spacing of the slices by $1.5 \mu \mathrm{m}$.

16

$17 \quad$ 2.9.2. Intracellular Spectroscopy

18 Single particle fluorescence images and spectra were collected by using a home-built sample 19 scanning confocal microscope. The $488 \mathrm{~nm}$ laser line from an Ar ion laser was used as the 20 excitation source. Samples were excited with $1 \mathrm{~W} / \mathrm{cm}^{2}$ laser light. The laser was focused using a 21 Zeiss 100x Fluar objective lens (NA 1.3, WD $0.17 \mathrm{~mm}$ ). The sample was raster scanned across

22 the focused laser beam using a Mad City Labs piezoelectric stage (Nano-LP100) to obtain a 23 fluorescence image of the sample. The fluorescence was detected by an avalanche photodiode 
1 (PerkinElmer SPCM-AQR-14). Fluorescence spectra were obtained by a spectrograph (Pl Acton

2 SP-2156) with the grating ( $150 \mathrm{~g} / \mathrm{mm}$ blaze: $500 \mathrm{~nm})$ centered at $600 \mathrm{~nm}$ which was coupled to a

3 thermoelectrically cooled electron multiplying charge coupled device (EM-CCD. Andor iXon

4 EM+ DU-897 BI). Each fluorescence spectrum was collected with 10 seconds exposure time for

53 consecutive frames and then averaged. Each spectrum shown in the manuscript is an average

6 built from 100 spectra, which were averaged into "ensemble spectra" in Matlab.

8 2.9.3. Epiluminescence Imaging for ROS detection

9 Imaging was completed with an Olympus IX71 microscope using a 60X objective and Andor

10 Zyla sCMOS (DG-152V-C1E-FI) camera. The DAPI channel was used for the nucleus and FITC

11 channel for CellROX green reagent imaging.

\section{3. Results and Discussion}

14 3.1. CPNP fabrication and characterization

15 The CPNPs were prepared by the reprecipitation method [69-71]. The resulting CPNPs are small 16 quasi-spherical clusters of about 20 to 50 polymer chains [72]. DLS data show that the CPNPs

17 have an average size of $34 \pm 6 \mathrm{~nm}$ in diameter with a narrow size distribution (Fig. 1B), consistent

18 with our previous reports [69]. The zeta potential of the CPNPs is $-12.4 \pm 3.7 \mathrm{mV}$, showing that

19 the CPNPs surface has a negative charge. The absorption and emission spectra of CPNPs

20 suspended in water shown in Fig. 1C depict a broad range of absorption in the visible spectrum

21 having an absorption maximum at $494 \mathrm{~nm}$ and an emission maximum at $591 \mathrm{~nm}$, respectively.

22 The CPNPs were observed to be stable in cell culture media for 96 hrs (data not shown) as

23 previously documented by Wu et al. [72]. 
2 3.2. In-vitro evaluation of CPNP uptake

3 Spherical nanoparticles of around $30 \mathrm{~nm}$ in diameter [73-75] and with positive zeta potential on

4 their surfaces are typically uptaken easily by cells [76-82]. The size range is approximated well

5 by the CPNPs discussed herein. While the surface charge is not ideal for cellular uptake, the

6 cancer cells are observed to internalize the CPNPs (vide infra). Fig. 2 shows the confocal

7 fluorescence images and corresponding phase contrast images of the cell lines incubated with 4

8 concentrations of CPNPs $\left(0 \mathrm{mg} / \mathrm{ml}, 0.4 \times 10^{-4} \mathrm{mg} / \mathrm{ml}, 2 \times 10^{-4} \mathrm{mg} / \mathrm{ml}\right.$ and $\left.3.6 \times 10^{-4} \mathrm{mg} / \mathrm{ml}\right)$,

9 revealing significant CPNP uptake. It can be seen that the different cell lines take up different

10 amounts of CPNPs and that the uptake is concentration dependent. The cancer cell lines

11 abundantly take up nanoparticles in comparison to the normal control cell line. It has been

12 reported that the charge on normal cell lines is highly negative whereas the cancer cell lines have

13 less negative charge on them [81,83]. Due to lesser negative charge on the cell surface of cancer

14 cells the CPNPs have less repulsion from the cancer cell line surfaces as compared to the normal

15 cell lines. Comparing the cancer cell lines, OVCAR3 has the highest uptake followed by A549

16 and lastly MDA-MB-231. The high uptake of CPNPs by OVCAR3 cells can be attributed to the

17 aggressiveness of this cell line [84-87].

18 CPNP uptake efficiency was further quantified by flow cytometry. Fig. 3A-D shows

19 representative normalized histograms indicating the distribution of fluorescence intensity

20 detected for cells incubated with CPNPs. All cell lines appear to have taken up nanoparticles,

21 although there is an apparent difference in extent of uptake. Cumulative analysis of the flow

22 cytometry data from two independent experiments was performed and the results were plotted as

23 bar graphs in Fig. 3E-F. The percent cell population that has internalized CPNPs is shown in 
1 Fig. 3E. The data show that $68.2 \%$ of TE-71 cells internalized CPNPs, while for MDA-MB-231,

2 A549, and OVCAR3 81.6\%, 85.6\%, and 90.05\% of the respective cells internalized CPNPs. The

3 average fluorescence intensity of CPNPs in each cell line is shown in Fig. 3F. The low average

4 fluorescence intensity observed for TE 71 implies that even though there are $68.2 \%$ cells which

5 have internalized CPNPs, the amount of CPNPs in each cell is very small. The OVCAR3 and

6 A549 cell lines exhibit comparable average fluorescence intensity of CPNPs followed by MDA-

7 MB-231. The flow cytometry data thus confirm the qualitative observations made by

8 fluorescence imaging (Fig. 2).

9 To confirm that the CPNPs were indeed internalized as opposed to being stuck to the outside cell

10 membrane, 3D confocal imaging experiments were completed. CPNPs are detected in the

11 intracellular environment throughout the 3D stack of images, as shown in Fig. 4 using A549 as a

12 representative example. Similar results were obtained for each cell line studied herein. These

13 images show that the CPNPs are located mostly at the periphery of the nucleus.

14 The stability of the CPNPs inside the cells was evaluated by Single Particle Spectroscopy. The

15 A549 cell line was selected for this experiment, since it internalizes CPNPs but not to the extent

16 that individual particles or clusters cannot be identified. Fig. 5A and $\mathbf{5 B}$ show the brightfield and

17 fluorescence image of a single A549 cell that internalized CPNPs. The expanded image in Fig.

18 5C allows for the observation of single CPNPs and clusters of CPNPs. These were individually

19 addressed by confocal laser and emission spectra collected for 100 CPNPs/CPNP clusters. The

20 resulting single particle ensemble spectrum is shown in Fig. 5D The peak emission at $588 \mathrm{~nm}$ is

21 comparable to the peak emission at $591 \mathrm{~nm}$ observed for freshly prepared CPNPs measured in

22 water. Conversely, well dissolved MEH-PPV in a good solvent emits around $553 \mathrm{~nm}$ [69]. These

23 data confirm that the CPNPs are stable and intact inside the cell. 
2 3.3. Intrinsic cytotoxicity of CPNPs

3 The intrinsic cytotoxicity of the CPNPs was evaluated quantitatively by MTT assays. Fig. 6

4 shows MTT data for the four cell lines incubated with three doses of CPNPs $\left(0.4 \times 10^{-4} \mathrm{mg} / \mathrm{ml}\right.$,

$52 \times 10^{-4} \mathrm{mg} / \mathrm{ml}$ and $\left.3.6 \times 10^{-4} \mathrm{mg} / \mathrm{ml}\right)$ together with the control $(0 \mathrm{mg} / \mathrm{ml})$. At no point is intrinsic

6 cytotoxicity of CPNPs observed. The cells proliferate normally in presence of CPNPs as

7 compared to the control dose. These data suggest that no ROS are formed in dark (vide infra), in

8 contrast to other sensitizers such as quantum dots, which even in the absence of light can still

9 lead to elevated ROS levels in cells, and cause damage to cell organelles or lead to cell death $10[88,89]$.

13 Fig. 7 shows MTT data quantifying the viability of the four studied cell lines loaded with the 14 CPNPs after PDT. The cell lines were incubated with three different concentrations $\left(0.4 \times 10^{-4}\right.$ $15 \mathrm{mg} / \mathrm{ml}, 2 \times 10^{-4} \mathrm{mg} / \mathrm{ml}$ and $3.6 \times 10^{-4} \mathrm{mg} / \mathrm{ml}$ ) of CPNPs and then exposed to different light doses $16\left(60 \mathrm{~J} / \mathrm{cm}^{2}, 120 \mathrm{~J} / \mathrm{cm}^{2}\right.$ or $\left.180 \mathrm{~J} / \mathrm{cm}^{2}\right)$. These moderate light doses are sufficient for an effective 17 PDT treatment, $[29,36,90,91]$ and are possible due to the large absorption cross section of MEH18 PPV used herein in the visible spectrum $\left(>10^{6} \mathrm{~L} / \mathrm{mol} \mathrm{cm}^{-1}\right)$. No phototoxicity effects were 19 observed in these studies (vide infra). Evaluation of treatment results was determined 20 immediately after the PDT application (Fig. 7A), and after an incubation period of 4 hours (Fig. 21 7B), and 12 hours (Fig. 7C). In each panel (Fig 7A, B and C) the cell viability at three CPNP 22 concentrations and three light doses are compared with the control for each cell line $(0 \mathrm{mg} / \mathrm{ml}$ 23 CPNPs). 
1 The cell viability for each waiting period decreases from TE-71 to MDA-MB-231 to A549 to

2 OVCAR3. In addition, for each cancer cell line, viability decreases with increasing CPNP dose,

3 although the highest dose $\left(3.6 \times 10^{-4} \mathrm{mg} / \mathrm{ml}\right)$ does not show significant improvement. For TE71

4 there is no significant CPNP dose response due to the limited CPNP uptake. For A549 and

5 OVCAR3 dependence on the light dose is also observed, where increasing light dose results in

6 lower viability. The $180 \mathrm{~J} / \mathrm{cm}^{2}$ light dose still shows measurable improvement in reducing cell

7 viability in those cases. This observation can again be attributed to the limited CPNP uptake by

8 TE71 and MDA-MB-231 in comparison to A549 and OVCAR3. In contrast, the higher amount

9 of CPNPs uptaken by cells lines such as A549 and OVCAR3 will lead to higher amounts of ROS

10 being generated upon irradiation, which is reflected in the observation of low cell viability. It is,

11 however, not possible to rule out the effects of differences in inherent ROS levels of different

12 cell lines on susceptibility to undergo oxidative stress through PDT [92,93].

13 Overall, effectiveness of PDT scales with the extent of CPNP uptake and administered light

14 dose. The $2 \times 10^{-4} \mathrm{mg} / \mathrm{ml}$ dose of CPNPs under light dose of $180 \mathrm{~J} / \mathrm{cm}^{2}$ was found to be most

15 effective. For the OVCAR3 cell line cell viability is near zero under these conditions.

\section{3.5. CPNPs as source of ROS}

18 It's been previously shown that conducting polymers are able to undergo charge- and energy

19 transfer from their triplet excited state to the ground state of oxygen to form singlet oxygen [94-

20 96]. The rapid photobleaching of conducting polymers, both reversible and irreversible, has been

21 attributed to this mechanism [97]. It was therefore hypothesized that CPNPs could yield ROS

22 upon photoirradiation without the need for photosensitizer dopants. Specifically, upon exposure

23 to light the CPNPs are photoexcited and in the case of MEH-PPV have an approximately $1.25 \%$ 
1 probability of intersystem crossing to the triplet excited state[98]. Oxygen can deactivate the

2 latter by energy transfer, which results in excitation of the oxygen triplet ground state to the

3 highly oxidative singlet oxygen excited state (Type II photosensitization) [35,36,38,99].

4 Alternatively, oxygen or other substrates such as solvent- and biomolecules can accept an

5 electron from the triplet excited state of the conducting polymer to form radicals (Type I

6 photosensitization) $[35,36,38,99]$. It has previously been shown that conducting polymers can

7 interact directly with oxygen to form superoxide in a reversible fashion $[97,100,101]$. If other

8 substrates are involved, then these typically act as intermediate radicals toward the formation of

9 superoxide. The superoxide anion may react further to form hydrogen peroxide, which in

10 presence of iron forms highly reactive hydroxyl radicals [42,102-104]. Regardless of whether

11 Type I or Type II photosensitization occurred, the resulting reactive oxygen then react with

12 biomolecules like lipids, nucleic acids etc. to form peroxides leading to a chain reaction in the

13 cell organelles causing damage to and potential death of the cell.

14 To confirm that the CPNPs are indeed the source of ROS formation in cells upon irradiation with

15 light, cells were stained with CellRox Green Reagent (CGR). This reagent is non-fluorescent or

16 very weakly fluorescent while in a reduced state and upon oxidation by ROS shows strong green

17 fluorescence. Formation of ROS was detected with CGR staining in A549 and OVCAR3 cell

18 lines that had taken up CPNPs and were exposed to light, both immediately after in-vitro PDT

19 (Fig. 8D) and 2 hours after PDT was completed (Fig. 8E). Further confirmation comes from the

20 control experiments with CGR staining. Fig. 8A-C shows three negative controls: in absence of

21 the treatment (no particles, no light), in absence of CPNPs with $180 \mathrm{~J} / \mathrm{cm}^{2}$ light dose, and in

22 absence of photoirradiation with $2 \times 10^{-4} \mathrm{mg} / \mathrm{ml}$ CPNPs dose, respectively. As CGR emission is

23 only detected when full PDT treatment is applied, it can be concluded that the CPNPs are the 
1 source of ROS under PDT. The data in Fig. 8B (no particles, $180 \mathrm{~J} / \mathrm{cm}^{2}$ light dose) suggest that

2 under the PDT conditions used here no acute phototoxicity occurs, since no elevated ROS levels

3 are detected and cell morphology looks normal. In addition, the data in Fig. 8C (particles, no

4 light) also support the MTT data that CPNP are not acutely cytotoxic, since no detectable ROS 5 response is observed in absence of light.

\section{4. Conclusions}

8 Conducting polymer poly[2-methoxy-5-(2-ethylhexyl-oxy)-p-phenylenevinylene] (MEH-PPV)

9 nanoparticles (CPNPs) were studied for application in biophotonics and therapeutics, specifically

10 for PDT. The nanoparticles are abundantly taken up by cancer cells without specific targeting of

11 surface receptors. Cells proliferate normally in the presence of CPNPs, indicating the absence of

12 intrinsic cytotoxicity. The bright intrinsic fluorescence of the CPNPs is attractive for localization

13 after administering the CPNPs, while the large absorption cross section allows for the use of low

14 to moderate light levels for ROS generation. It was observed that the effectiveness of PDT scales

15 with the extent of CPNP uptake and administered light dose. The $2 \times 10^{-4} \mathrm{mg} / \mathrm{ml}$ dose of CPNPs

16 under light dose of $180 \mathrm{~J} / \mathrm{cm}^{2}$ was found to be the most effective treatment scheme in-vitro.

17 Promisingly, for the OVCAR3 cell line cell viability is near zero under these conditions. 


\section{Acknowledgements}

2 AJG and MD thank the National Science Foundation (NSF) for financial support of this work

3 through a CAREER award (CBET-0746210), and through award CBET-1159500. 
2 [1] Dent S, Oyan B, Honig A, Mano M, Howell S. HER2-targeted therapy in breast cancer: A 3 systematic review of neoadjuvant trials. Cancer Treat Rev 2013;39:622-631.

4 [2] Heinemann V, Douillard JY, Ducreux M, Peeters M. Targeted therapy in metastatic 5 colorectal cancer - An example of personalised medicine in action. Cancer Treat Rev $6 \quad 2013 ; 39: 592-601$.

7 [3] Mountzios G, Soultati A, Pectasides D, Pectasides E, Dimopoulos MA, Papadimitriou CA. 8 Developments in the systemic treatment of metastatic cervical cancer. Cancer Treat Rev $9 \quad 2013 ; 39: 430-443$.

10 [4] Verbrugghe M, Verhaeghe S, Lauwaert K, Beeckman D, Van Hecke A. Determinants and 11 associated factors influencing medication adherence and persistence to oral anticancer drugs: A 12 systematic review. Cancer Treat Rev 2013;39:610-621.

13 [5] Xie X, Wang SS, Wong TCS, Fung MC. Genistein promotes cell death of ethanol-stressed 14 HeLa cells through the continuation of apoptosis or secondary necrosis. Cancer Cell Int $15 \quad 2013 ; 13: 1-15$.

16 [6] Fisher B, Anderson S, Bryant J, Margolese RG, Deutsch M, Fisher ER, et al. Twenty-Year 17 Follow-up of a Randomized Trial Comparing Total Mastectomy, Lumpectomy, and 18 Lumpectomy plus Irradiation for the Treatment of Invasive Breast Cancer. N Engl J Med $19 \quad 2002 ; 347: 1233-1241$.

20 [7] Fong Y, Fortner J, Sun RL, Brennan MF, Blumgart LH. Clinical Score for Predicting 21 Recurrence After Hepatic Resection for Metastatic Colorectal Cancer: Analysis of 1001 22 Consecutive Cases. Annals of Surgery 1999;230:309. 
1 [8] Ishitobi M, Suzuki O, Komoike Y, Ohsumi S, Nakahara S, Yagi T, et al. Phase II study of

2 neoadjuvant anastrozole and concurrent radiotherapy for postmenopausal breast cancer patients.

3 Breast Cancer 2014;21:550-556.

4 [9] Kalbasi A, June CH, Haas N, Vapiwala N. Radiation and immunotherapy: a synergistic 5 combination. J Clin Invest 2013;123:2756-2763.

6 [10] Suneja G, Poorvu PD, Hill-Kayser C, Lustig RA. Acute toxicity of proton beam radiation

7 for pediatric central nervous system malignancies. Pediatr Blood Cancer 2013;60:1431-1436.

8 [11] Aketa H, Tatsumi T, Kohga K, Tsunematsu H, Aono S, Shimizu S, et al. The combination 9 therapy of alpha-galactosylceramide and 5-fluorouracil showed antitumor effect synergistically 10 against liver tumor in mice. Int J Cancer 2013;133:1126-1134.

11 [12] Hussain M, Javeed A, Ashraf M, Hou YZ, Mukhtar MM. Multilevel pharmacological 12 manipulation of adenosine-prostaglandin E-2/cAMP nexus in the tumor microenvironment: A 13 'two hit' therapeutic opportunity. Pharmacol Res 2013;73:8-19.

14 [13] Ghattass K, Assah R, El-Sabban M, Gali-Muhtasib H. Targeting Hypoxia for Sensitization 15 of Tumors to Radio- and Chemotherapy. Curr Cancer Drug Targets 2013;13:670-685.

16 [14] Kumar A, Cascarini L, McCaul JA, Kerawala CJ, Coombes D, Godden D, et al. How should 17 we manage oral leukoplakia? Br J Oral Maxillofac Surg 2013;51:377-383.

18 [15] Milovanovic J, Djukic V, Milovanovic A, Jotic A, Banko B, Jesic S, et al. Clinical outcome 19 of early glottic carcinoma in Serbia. Auris Nasus Larynx 2013;40:394-399.

20 [16] Moore EJ, Hinni ML. Critical Review: Transoral Laser Microsurgery and Robotic-Assisted 21 Surgery for Oropharynx Cancer Including Human Papillomavirus-Related Cancer. Int J Radiat 22 Oncol Biol Phys 2013;85:1163-1167. 
1 [17] No D, Osterberg EC, Otto B, Naftali I, Choi B. Evaluation of continence following 532nm

2 laser prostatectomy for patients previously treated with radiation therapy or brachytherapy.

3 Lasers Surg Med 2013;45:358-361.

4 [18] Rosch T. Progress in endoscopy: areas of current interest and topics to watch out for. 5 Endoscopy 2012;44:1148-1157.

6 [19] Stummer W, Pichlmeier U, Meinel T, Wiestler OD, Zanella F, Reulen H-Jr. Fluorescence-

7 guided surgery with 5-aminolevulinic acid for resection of malignant glioma: a randomised

8 controlled multicentre phase III trial. The Lancet Oncology 2006;7:392-401.

9 [20] Troyan S, Kianzad V, Gibbs-Strauss S, Gioux S, Matsui A, Oketokoun R, et al. The FLARE

10 Intraoperative Near-Infrared Fluorescence Imaging System: A First-in-Human Clinical Trial in

11 Breast Cancer Sentinel Lymph Node Mapping. Annals of Surgical Oncology 2009;16:2943122952.

13 [21] De Beer EL, Bottone AE, Voest EE. Doxorubicin and mechanical performance of cardiac 14 trabeculae after acute and chronic treatment: a review. European Journal of Pharmacology $15 \quad 2001 ; 415: 1-11$.

16 [22] Joseph MMA, S. R. ;George, S. K. ;Pillai, K. R. ;Mini, S. ;Sreelekha, T. T. . 17 Galactoxyloglucan-Modified Nanocarriers of Doxorubicin for Improved Tumor-Targeted Drug 18 Delivery with Minimal Toxicity. Journal of Biomedical Nanotechnology 2014;10:3253-3268.

19 [23] Keizer HG, Pinedo HM, Schuurhuis GJ, Joenje H. Doxorubicin (adriamycin): A critical 20 review of free radical-dependent mechanisms of cytotoxicity. Pharmacology \& Therapeutics $21 \quad 1990 ; 47: 219-231$.

22 [24] Fagard R, Metelev V, Souissi Is, Baran-Marszak F. STAT3 inhibitors for cancer therapy: 23 Have all roads been explored? JAK-STAT 2013;2:e22882. 
1 [25] Turkson JJ, R. STAT proteins: novel molecular targets for cancer drug discovery. Oncogene $2 \quad 2000 ; 19: 6613-6626$.

3 [26] Zhang X, Yue P, Page BDG, Li T, Zhao W, Namanja AT, et al. Orally bioavailable small-

4 molecule inhibitor of transcription factor Stat3 regresses human breast and lung cancer 5 xenografts. Proceedings of the National Academy of Sciences 2012;109:9623-9628.

6 [27] Davis ME, Chen Z, Shin DM. Nanoparticle therapeutics: an emerging treatment modality

7 for cancer. Nat Rev Drug Discov 2008;7:771-782.

8 [28] Vyas DC, P. ;Saadeh, Y. ;Vyas, A. . The Role of Nanotechnology in Gastrointestinal

9 Cancer. Journal of Biomedical Nanotechnology 2014;10:3204-3218.

10 [29] Brown SB, Brown EA, Walker I. The present and future role of photodynamic therapy in 11 cancer treatment. The Lancet Oncology 2004;5:497-508.

12 [30] Buinauskaite E, Maciulaitis R, Buinauskiene J, Valiukeviciene S. Topical photodynamic 13 therapy of actinic keratoses with 5-aminolevulinic acid: Randomized controlled trial with six 14 months follow-up. Journal of Dermatological Treatment 2014;25:519-522.

15 [31] Casie Chetty N, Hemmant B, Skellett A-M. Periocular photodynamic therapy for squamous 16 intra-epidermal carcinoma. Journal of Dermatological Treatment 2014;25:516-518.

17 [32] Gupta A, Avci P, Sadasivam M, Chandran R, Parizotto N, Vecchio D, et al. Shining light on 18 nanotechnology to help repair and regeneration. Biotechnol Adv 2012;31:607-631.

19 [33] Hopper C. Photodynamic therapy: a clinical reality in the treatment of cancer. The Lancet 20 Oncology 2000;1:212-219.

21 [34] Kubler AC. Photodynamic therapy. Medical Laser Application 2005;20:37-45.

22 [35] Dolmans D, Fukumura D, Jain RK. Photodynamic therapy for cancer. Nat Rev Cancer $23 \quad 2003 ; 3: 380-387$. 
1 [36] Dougherty TJ, Gomer CJ, Henderson BW, Jori G, Kessel D, Korbelik M, et al.

2 Photodynamic Therapy. J Natl Cancer Inst 1998;90:889-905.

3 [37] Ferrari M. Cancer nanotechnology: Opportunities and challenges. Nat Rev Cancer $4 \quad 2005 ; 5: 161-171$.

5 [38] Oleinick NL, Morris RL, Belichenko T. The role of apoptosis in response to photodynamic 6 therapy: what, where, why, and how. Photochem Photobiol Sci 2002;1:1-21.

7 [39] Pass HI. Photodynamic Therapy in Oncology - Mechanisms and Clinical Use. J Natl Cancer $8 \quad$ Inst 1993;85:443-456.

9 [40] Droge W. Free radicals in the physiological control of cell function. Physiol Rev $10 \quad 2002 ; 82: 47-95$.

11 [41] Valko M, Leibfritz D, Moncol J, Cronin MTD, Mazur M, Telser J. Free radicals and 12 antioxidants in normal physiological functions and human disease. International Journal of 13 Biochemistry \& Cell Biology 2007;39:44-84.

14 [42] Valko M, Rhodes CJ, Moncol J, Izakovic M, Mazur M. Free radicals, metals and 15 antioxidants in oxidative stress-induced cancer. Chem-Biol Interact 2006;160:1-40.

16 [43] Wallace DC. A mitochondrial paradigm of metabolic and degenerative diseases, aging, and 17 cancer: A dawn for evolutionary medicine. Annual Review of Genetics; 2005. p. 359-407.

18 [44] Huang P, Trachootham D, Alexandre J. Targeting cancer cells by ROS-mediated 19 mechanisms: a radical therapeutic approach? Nat Rev Drug Discov 2009;8:579-591.

20 [45] Huang P, Trachootham D, Zhou Y, Zhang H, Demizu Y, Chen Z, et al. Selective killing of 21 oncogenically transformed cells through a ROS-mediated mechanism by beta-phenylethyl 22 isothiocyanate. Cancer Cell 2006;10:241-252. 
1 [46] Nogueira V, Park Y, Chen C-C, Xu P-Z, Chen M-L, Tonic I, et al. Akt Determines

2 Replicative Senescence and Oxidative or Oncogenic Premature Senescence and Sensitizes Cells

3 to Oxidative Apoptosis. Cancer Cell 2008;14:458-470.

4 [47] Schumacker PT. Reactive oxygen species in cancer cells: Live by the sword, die by the 5 sword. Cancer Cell 2006;10:175-176.

6 [48] Chen J-Y, Lee Y-M, Zhao D, Mak N-K, Wong RN-S, Chan W-H, et al. Quantum Dot-

7 mediated Photoproduction of Reactive Oxygen Species for Cancer Cell Annihilation.

8 Photochemistry and Photobiology 2010;86:431-437.

9 [49] Chou KL, Meng H, Cen Y, Li L, Chen JY. Dopamine-quantum dot conjugate: a new kind of 10 photosensitizers for photodynamic therapy of cancers. J Nanopart Res 2013;15:9.

11 [50] Huang P, Lin J, Wang S, Zhou Z, Li Z, Wang Z, et al. Photosensitizer-conjugated silica12 coated gold nanoclusters for fluorescence imaging-guided photodynamic therapy. Biomaterials $13 \quad 2013 ; 34: 4643-4654$.

14 [51] Ito S, Miyoshi N, Degraff WG, Nagashima K, Kirschenbaum LJ, Riesz P. Enhancement of 15 5-Aminolevulinic acid-induced oxidative stress on two cancer cell lines by gold nanoparticles.

16 Free Radic Res 2009;43:1214-1224.

17 [52] Vankayala R, Huang Y-K, Kalluru P, Chiang C-S, Hwang KC. First Demonstration of Gold 18 Nanorods-Mediated Photodynamic Therapeutic Destruction of Tumors via Near Infra-Red Light 19 Activation. Small 2013;10:1612-1622.

20 [53] Perrier M, Gary-Bobo M, Lartigue L, Brevet D, Morere A, Garcia M, et al. Mannose21 functionalized porous silica-coated magnetic nanoparticles for two-photon imaging or PDT of 22 cancer cells. J Nanopart Res 2013;15:17. 
1 [54] Wang F, Chen XL, Zhao ZX, Tang SH, Huang XQ, Lin CH, et al. Synthesis of magnetic,

2 fluorescent and mesoporous core-shell-structured nanoparticles for imaging, targeting and

3 photodynamic therapy. J Mater Chem 2011;21:11244-11252.

4 [55] Kim S, Ohulchanskyy TY, Pudavar HE, Pandey RK, Prasad PN. Organically modified silica

5 nanoparticles co-encapsulating photosensitizing drug and aggregation-enhanced two-photon

6 absorbing fluorescent dye aggregates for two-photon photodynamic therapy. J Am Chem Soc

$7 \quad 2007 ; 129: 2669-2675$.

8 [56] Tao X, Yang Y-J, Liu S, Zheng Y-Z, Fu J, Chen J-F. Poly(amidoamine) dendrimer-grafted

9 porous hollow silica nanoparticles for enhanced intracellular photodynamic therapy. Acta

10 Biomaterialia 2013;9:6431-6438.

11 [57] Zhao ZX, Huang YZ, Shi SG, Tang SH, Li DH, Chen XL. Cancer therapy improvement

12 with mesoporous silica nanoparticles combining photodynamic and photothermal therapy.

13 Nanotechnology 2014;25:285701.

14 [58] Ohulchanskyy TY, Roy I, Goswami LN, Chen Y, Bergey EJ, Pandey RK, et al. Organically

15 Modified Silica Nanoparticles with Covalently Incorporated Photosensitizer for Photodynamic

16 Therapy of Cancer. Nano Letters 2007;7:2835-2842.

17 [59] Xue C, Wu J, Lan F, Liu W, Yang X, Zeng F, et al. Nano Titanium Dioxide Induces the

18 Generation of ROS and Potential Damage in HaCaT Cells Under UVA Irradiation. Journal of

19 Nanoscience and Nanotechnology 2010;10:8500-8507.

20 [60] Ding H, Mora R, Gao J, Sumer BD. Characterization and Optimization of mTHPP

21 Nanoparticles for Photodynamic Therapy of Head and Neck Cancer. Otolaryngology -- Head and

22 Neck Surgery 2011;145:612-617. 
1 [61] Kameyama NM, S. ;Itano, O. ;Ito, A. ;Konno, T. ;Arai, T. ;Ishihara, K. ;Ueda, M.

2 ;Kitagawa, Y. Photodynamic Therapy Using an Anti-EGF Receptor Antibody Complexed with

3 Verteporfin Nanoparticles: A Proof of Concept Study. Cancer Biotherapy and

4 Radiopharmaceuticals 2011;26:697-704.

5 [62] Derycke ASL, de Witte PAM. Liposomes for photodynamic therapy. Adv Drug Deliv Rev $6 \quad 2004 ; 56: 17-30$.

7 [63] Choi KHC, C. W. ;Kim, C. H. ;Kim, D. H. ;Jeong, Y. I. ;Kang, D. H. . Effect of 58 Aminolevulinic Acid-Encapsulate Liposomes on Photodynamic Therapy in Human 9 Cholangiocarcinoma Cells. Journal of Nanoscience and Nanotechnology 2014;14:5628-5632.

10 [64] Figueira Fv, M.R. Pereira P, Silva S, A.S. Cavaleiro J, P.C. Tome J. Porphyrins and 11 Phthalocyanines Decorated with Dendrimers: Synthesis and Biomedical Applications. Current 12 Organic Synthesis 2014;11:110-126.

13 [65] Taratula O, Schumann C, Naleway MA, Pang AJ, Chon KJ, Taratula O. A Multifunctional 14 Theranostic Platform Based on Phthalocyanine-Loaded Dendrimer for Image-Guided Drug 15 Delivery and Photodynamic Therapy. Mol Pharm 2013;10:3946-3958.

16 [66] Grimland JL, Wu C, Ramoutar RR, Brumaghim JL, McNeill J. Photosensitizer-doped 17 conjugated polymer nanoparticles with high cross-sections for one- and two-photon excitation. 18 Nanoscale3:1451-1455.

19 [67] Shen X, Li L, Wu H, Yao SQ, Xu Q-H. Photosensitizer-doped conjugated polymer 20 nanoparticles for simultaneous two-photon imaging and two-photon photodynamic therapy in 21 living cells. Nanoscale3:5140-5146. 
1 [68] Zhang Y, Pang L, Ma C, Tu Q, Zhang R, Saeed E, et al. Small Molecule-Initiated Light-

2 Activated Semiconducting Polymer Dots: An Integrated Nanoplatform for Targeted

3 Photodynamic Therapy and Imaging of Cancer Cells. Analytical Chemistry 2014;86:3092-3099.

4 [69] Tenery D, Worden JG, Hu Z, Gesquiere AJ. Single particle spectroscopy on composite

5 MEH-PPV/PCBM nanoparticles. Journal of Luminescence 2009;129:423-429.

6 [70] Wu C, Peng H, Jiang Y, McNeill J. Energy Transfer Mediated Fluorescence from Blended

7 Conjugated Polymer Nanoparticles. The Journal of Physical Chemistry B 2006;110:14148814154.

9 [71] Kasai H, Nalwa HS, Oikawa H, Okada S, Matsuda H, Minami N, et al. A Novel Preparation 10 Method of Organic Microcrystals. Japanese Journal of Applied Physics Part 2-Letters 11 1992;31:L1132-L1134.

12 [72] Wu C, Bull B, Szymanski C, Christensen K, McNeill J. Multicolor Conjugated Polymer 13 Dots for Biological Fluorescence Imaging. ACS Nano 2008;2:2415-2423.

14 [73] Gao HJ, Shi WD, Freund LB. Mechanics of receptor-mediated endocytosis. Proc Natl Acad 15 Sci U S A 2005;102:9469-9474.

16 [74] Lerch S, Dass M, Musyanovych A, Landfester K, Mailander V. Polymeric nanoparticles of 17 different sizes overcome the cell membrane barrier. Eur J Pharm Biopharm 2013;84:265-274.

18 [75] Tang L, Gabrielson NP, Uckun FM, Fan TM, Cheng JJ. Size-Dependent Tumor Penetration 19 and in Vivo Efficacy of Monodisperse Drug-Silica Nanoconjugates. Mol Pharm 2013;10:88320892.

21 [76] Chung YI, Kim JC, Kim YH, Tae G, Lee SY, Kim K, et al. The effect of surface 22 functionalization of PLGA nanoparticles by heparin- or chitosan-conjugated Pluronic on tumor 23 targeting. J Control Release143:374-382. 
1 [77] Clift MJD, Rothen-Rutishauser B, Brown DM, Duffin R, Donaldson K, Proudfoot L, et al.

2 The impact of different nanoparticle surface chemistry and size on uptake and toxicity in a 3 murine macrophage cell line. Toxicol Appl Pharmacol 2008;232:418-427.

4 [78] Gratton SEA, Ropp PA, Pohlhaus PD, Luft JC, Madden VJ, Napier ME, et al. The effect of 5 particle design on cellular internalization pathways. Proc Natl Acad Sci U S A 2008;105:11613$6 \quad 11618$.

7 [79] Xia T, Kovochich M, Liong M, Zink JI, Nel AE. Cationic polystyrene nanosphere toxicity 8 depends on cell-specific endocytic and mitochondrial injury pathways. ACS Nano 2008;2:85-96. 9 [80] Xu PS, Van Kirk EA, Zhan YH, Murdoch WJ, Radosz M, Shen YQ. Targeted charge10 reversal nanoparticles for nuclear drug delivery. Angew Chem-Int Edit 2007;46:4999-5002.

11 [81] Zhang Y, Yang M, Portney NG, Cui DX, Budak G, Ozbay E, et al. Zeta potential: a surface 12 electrical characteristic to probe the interaction of nanoparticles with normal and cancer human 13 breast epithelial cells. Biomed Microdevices 2008;10:321-328.

14 [82] Huhn D, Kantner K, Geidel C, Brandholt S, De Cock I, Soenen SJH, et al. Polymer-Coated 15 Nanoparticles Interacting with Proteins and Cells: Focusing on the Sign of the Net Charge. ACS 16 Nano 2013;7:3253-3263.

17 [83] Cook GM, Jacobson W. The electrophoretic mobility of normal and leukaemic cells of 18 mice. . Biochem J 1968;4:549-557.

19 [84] Parker N, Turk MJ, Westrick E, Lewis JD, Low PS, Leamon CP. Folate receptor expression 20 in carcinomas and normal tissues determined by a quantitative radioligand binding assay. 21 Analytical Biochemistry 2005;338:284-293. 
1 [85] Ross JF, Chaudhuri PK, Ratnam M. Differential regulation of folate receptor isoforms in

2 normal and malignant tissues in vivo and in established cell lines. Physiologic and clinical

3 implications. Cancer 1994;73:2432-2443.

4 [86] Toffoli G, Cernigoi C, Russo A, Gallo A, Bagnoli M, Boiocchi M. Overexpression of folate 5 binding protein in ovarian cancers. Int J Cancer 1997;74:193-198.

6 [87] Zhou H, Liu X, Liu L, Yang Z, Zhang S, Tang M, et al. Oxidative Stress and Apoptosis of 7 Human Brain Microvascular Endothelial Cells Induced by Free Fatty Acids. J Int Med Res $8 \quad 2009 ; 37: 1897-1903$.

9 [88] Green M, Howman E. Semiconductor quantum dots and free radical induced DNA nicking.

10 Chemical Communications 2005;121-123.

11 [89] Lovric J, Cho SJ, Winnik FoM, Maysinger D. Unmodified Cadmium Telluride Quantum

12 Dots Induce Reactive Oxygen Species Formation Leading to Multiple Organelle Damage and

13 Cell Death. Chemistry \&amp; Biology 2005;12:1227-1234.

14 [90] Peng Q, Warloe T, Berg K, Moan J, Kongshaug M, Giercksky K-E, et al. 5-Aminolevulinic 15 acid-based photodynamic therapy. Cancer 1997;79:2282-2308.

16 [91] Kawase Y, Iseki H. Parameter-finding studies of photodynamic therapy for approval in 17 Japan and the USA. Photodiagnosis and Photodynamic Therapy 2013;10:434-445.

18 [92] Gao F, Yi J, Yuan JQ, Shi GY, Tang XM. The cell cycle related apoptotic susceptibility to 19 arsenic trioxide is associated with the level of reactive oxygen species. Cell Res 2004;14:81-85.

20 [93] Yi J, Gao F, Shi G, Li H, Wang Z, Shi X, et al. The inherent cellular level of reactive 21 oxygen species: One of the mechanisms determining apoptotic susceptibility of leukemic cells to 22 arsenic trioxide. Apoptosis 2002;7:209-215. 
1 [94] Gesquiere AJ, Park S-J, Barbara PF. Hole-Induced Quenching of Triplet and Singlet

2 Excitons in Conjugated Polymers. J Am Chem Soc 2005;127:9556-9560.

3 [95] Halas NJ, Hale GD, Oldenburg SJ. Dynamics of triplet excitons in MEH-PPV measured by

4 two-photon photoemission. Proc SPIE, Optical Probes of Conjugated Polymers 1997;3145:2295239.

6 [96] Monkman AP, Burrows HD, da G. Miguel M, Hamblett I, Navaratnam S. Measurement of

7 the S0-T1 energy gap in poly(2-methoxy,5-(2'-ethyl-hexoxy)-p-phenylenevinylene) by triplet-

8 triplet energy transfer. Chemical Physics Letters 1999;307:303-309.

9 [97] Gesquiere AJ, Park S-J, Barbara PF. F-V/SMS: A New Technique for Studying the 10 Structure and Dynamics of Single Molecules and Nanoparticles. The Journal of Physical 11 Chemistry B 2004;108:10301-10308.

12 [98] Burrows HD, Seixas de Melo J, Serpa C, Arnaut LG, Miguel MdG, Monkman AP, et al. 13 Triplet state dynamics on isolated conjugated polymer chains. Chemical Physics 2002;285:3-11.

14 [99] Henderson BW, Dougherty TJ. How Does Photodynamic Therapy Work? Photochemistry 15 and Photobiology 1992;55:145-157.

16 [100] Park S-J, Gesquiere AJ, Yu J, Barbara PF. Charge Injection and Photooxidation of Single 17 Conjugated Polymer Molecules. J Am Chem Soc 2004;126:4116-4117.

18 [101] Chambon S, Rivaton A, Gardette J-L, Firon M. Reactive intermediates in the initiation step 19 of the photo-oxidation of MDMO-PPV. Journal of Polymer Science Part A: Polymer Chemistry $20 \quad 2009 ; 47: 6044-6052$.

21 [102] Fariss MW, Chan CB, Patel M, Van Houten B, Orrenius S. Defining mitochondrial targets 22 to combat the pleiotropic effects of toxic oxidative stress. Mol Interv 2005;5:94-111. 
1 [103] Halliwell B, Chirico S. Lipid-Peroxidation - Its Mechanism, Measurement, and

2 Significance. Am J Clin Nutr 1993;57:S715-S725.

3 [104] Halliwell BG, J. M. C. . Oxygen-Toxicity, Oxygen Radicals, Transition-Metals and

4 Disease. Biochemical Journal 1984;219:1-14. 

11 stained with DAPI.

12

\section{Figure Captions} (blue).

Fig. 1. A) Chemical structure of the conducting polymer MEH-PPV. Size distribution of CPNPs obtained by dynamic light scattering. The average size of the CPNPs is $34 \pm 6 \mathrm{~nm}$. C) Absorbance (red line) and emission (black line) spectra of CPNPs in water.

Fig. 2. From top to bottom confocal fluorescence images and corresponding phase contrast images of TE-71, MDA-MB-231, A549 and OVCAR3 cells incubated with increasing doses of CPNPs. CPNP doses are indicated at the top of the figure and are expressed in units of $10^{-4}$ $\mathrm{mg} / \mathrm{ml}$. Green dots represent the fluorescence from CPNPs and the blue color indicates nuclei

Fig. 3. Flow cytometry data on uptake of CPNPs by each cell line. Representative data showing normalized cell count of A) TE 71, B) MDA-MB-231, C) A549 and D) OVCAR3 cell lines with respect to detected CPNP fluorescence. E) Percentage of the cell population for each cell line that has internalized CPNPs (green bars) together with controls (red bars, no CPNPs, n=2), F) Average fluorescence intensity detected from CPNPs for each cell line depicted by green bars, together with controls (red bars, no CPNPs, $n=2$ ). The geometric mean of the fluorescence intensity distribution was used to plot the bar graphs in $(\mathrm{F})$.

Fig. 4. Confocal slices of an A549 cell with CPNPs (green dots) at the periphery of the nucleus 
1 Fig. 5. Single particle imaging and spectroscopy on CPNPs inside A549 cells. A) Bright field

2 image of an A549 cell. B) Raster-scanned fluorescence image of the corresponding A549 cell

3 with CPNPs inside the cell. The CPNPs can be seen clearly as spherical bright spots in the

4 magnified region of the image shown in panel C). D) The ensemble spectrum of CPNPs inside

5 the cell (black line) has $\lambda_{\max }$ at $588 \mathrm{~nm}$. The spectral shape and emission maximum indicate that

6 the CPNPs remain stable in the intracellular environment. The inset in D) shows the

7 autofluorescence of the cell with $\lambda_{\max } 550 \mathrm{~nm}$. A shoulder at this wavelength can be seen in the 8 spectrum of CPNPs.

9

10 Fig. 6. MTT viability assays to evaluate the intrinsic cytotoxicity of CPNPs. A) TE-71, B)

11 MDA-MB-231, C) A549 and D) OVCAR3 with control dose $(0 \mathrm{mg} / \mathrm{ml})$ and three doses of

12 CPNPs $\left(0.4 \times 10^{-4} \mathrm{mg} / \mathrm{ml}, 2 \times 10^{-4} \mathrm{mg} / \mathrm{ml}\right.$ and $\left.3.6 \times 10^{-4} \mathrm{mg} / \mathrm{ml}\right)$. The incubation periods are 0,24 , 1348,72 and 96 hours.

15 Fig. 7. MTT assay to evaluate the cell viability after application of PDT. Post-PDT incubation 16 period A) 0 hours, B) 4 hours, and C) 12 hours. Each panel has four cell lines, TE-71, MDA17 MB-231, A549 and OVCAR3. Each cell line is administered with three doses of CPNPs $\left(0.4 \times 10^{-}\right.$

$18{ }^{4} \mathrm{mg} / \mathrm{ml}, 2 \times 10^{-4} \mathrm{mg} / \mathrm{ml}$ and $3.6 \times 10^{-4} \mathrm{mg} / \mathrm{ml}$ ) and $0 \mathrm{mg} / \mathrm{ml}$ as the control dose. The colored bars 19 represent dose of light (red: $60 \mathrm{~J} / \mathrm{cm}^{2}$, green: $120 \mathrm{~J} / \mathrm{cm}^{2}$, blue: $180 \mathrm{~J} / \mathrm{cm}^{2}$ ).

21 Fig. 8. Epiluminescence images with corresponding phase contrast images of A549 and 22 OVCAR3 cell lines for detection of ROS in by CellRox green reagent. A) Control in absence of 23 treatment (no CPNPs, no light). B) Negative control by means of light exposure in absence 
1 CPNPs. C) Negative control by means of incubation with CPNPs in absence of light exposure.

2 CPNP emission can be detected. D) Fluorescence images taken immediately after PDT, and E) 2

3 hours post-PDT. F) Positive control with $100 \mu \mathrm{M} \mathrm{H}_{2} \mathrm{O}_{2}$. 

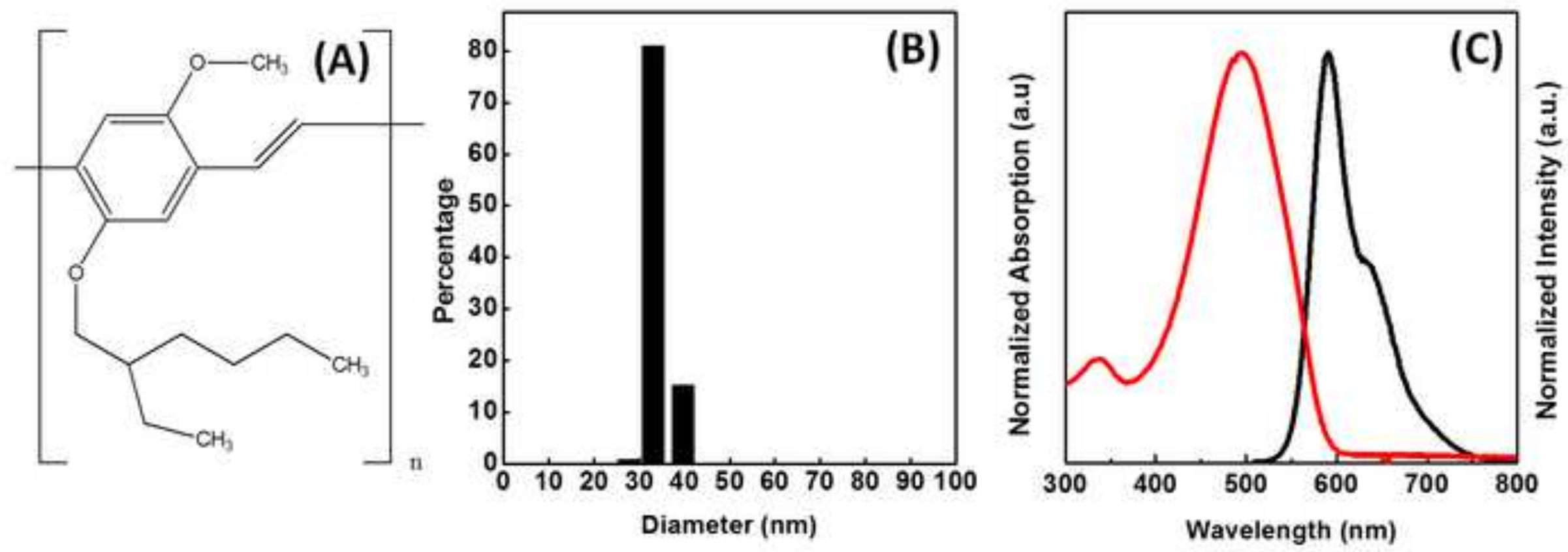

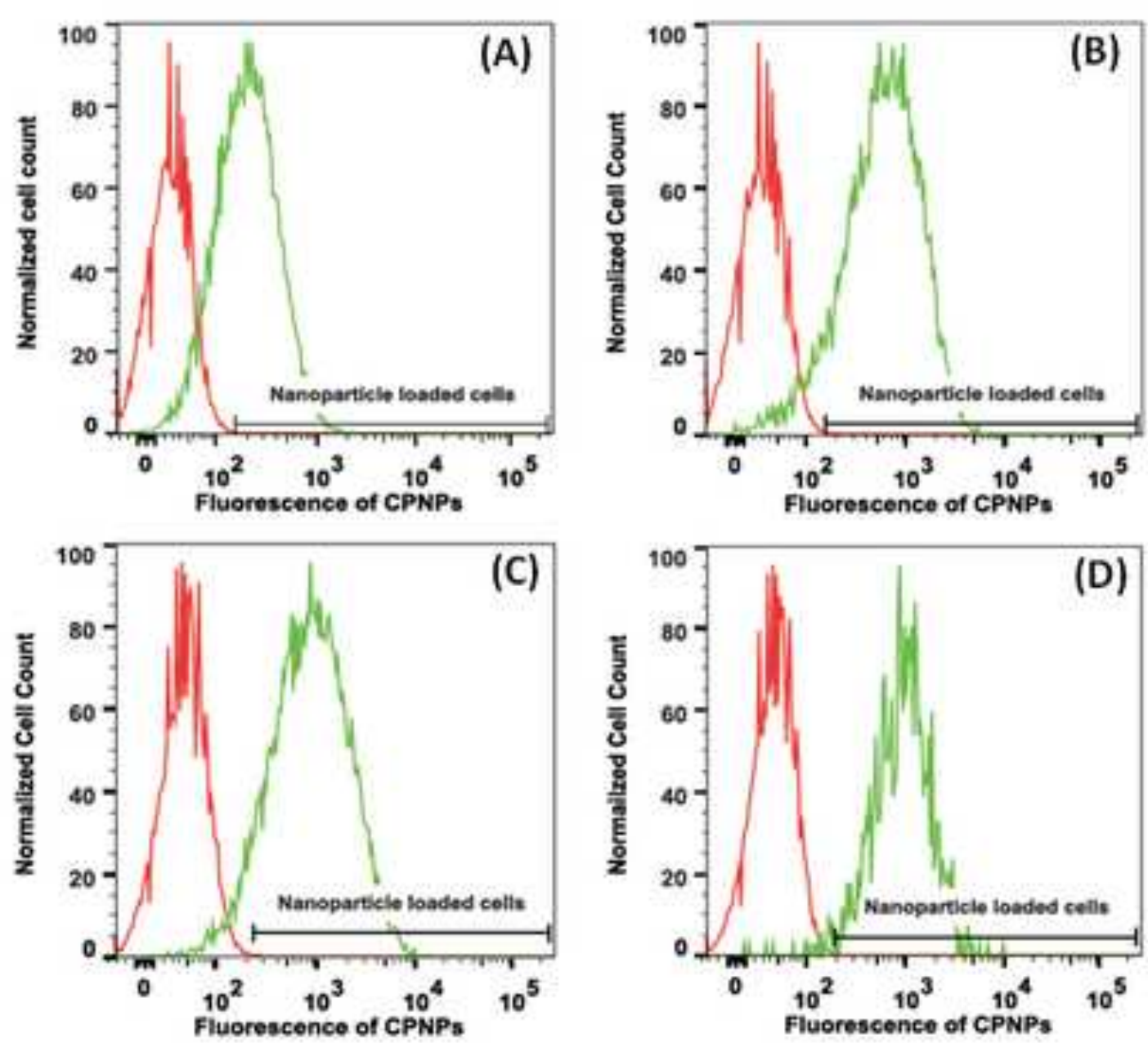

(E)

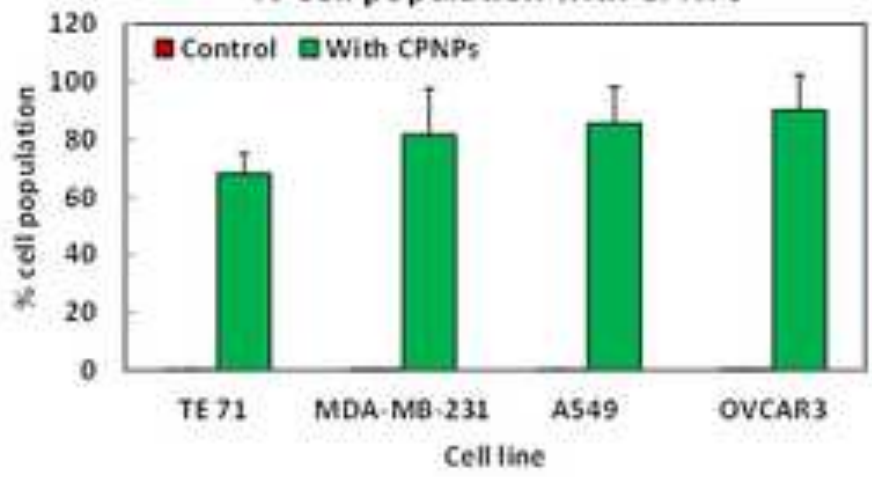

(F)

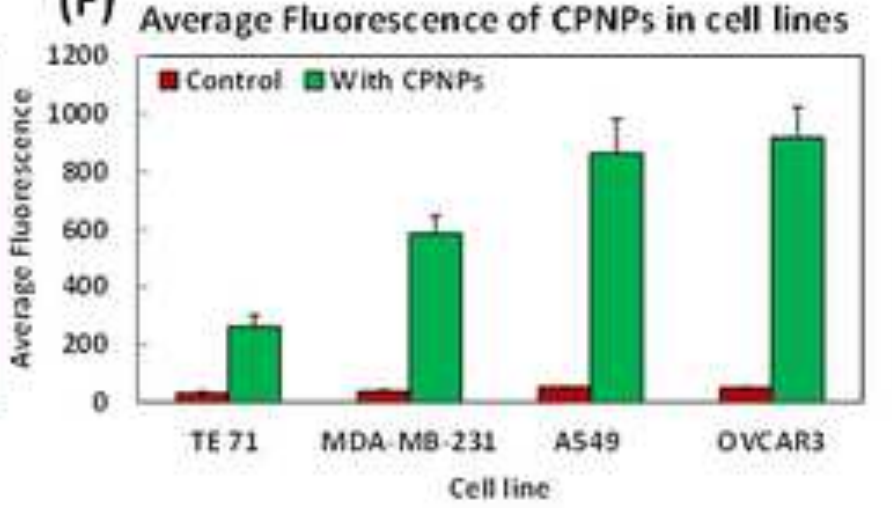


Figure 4
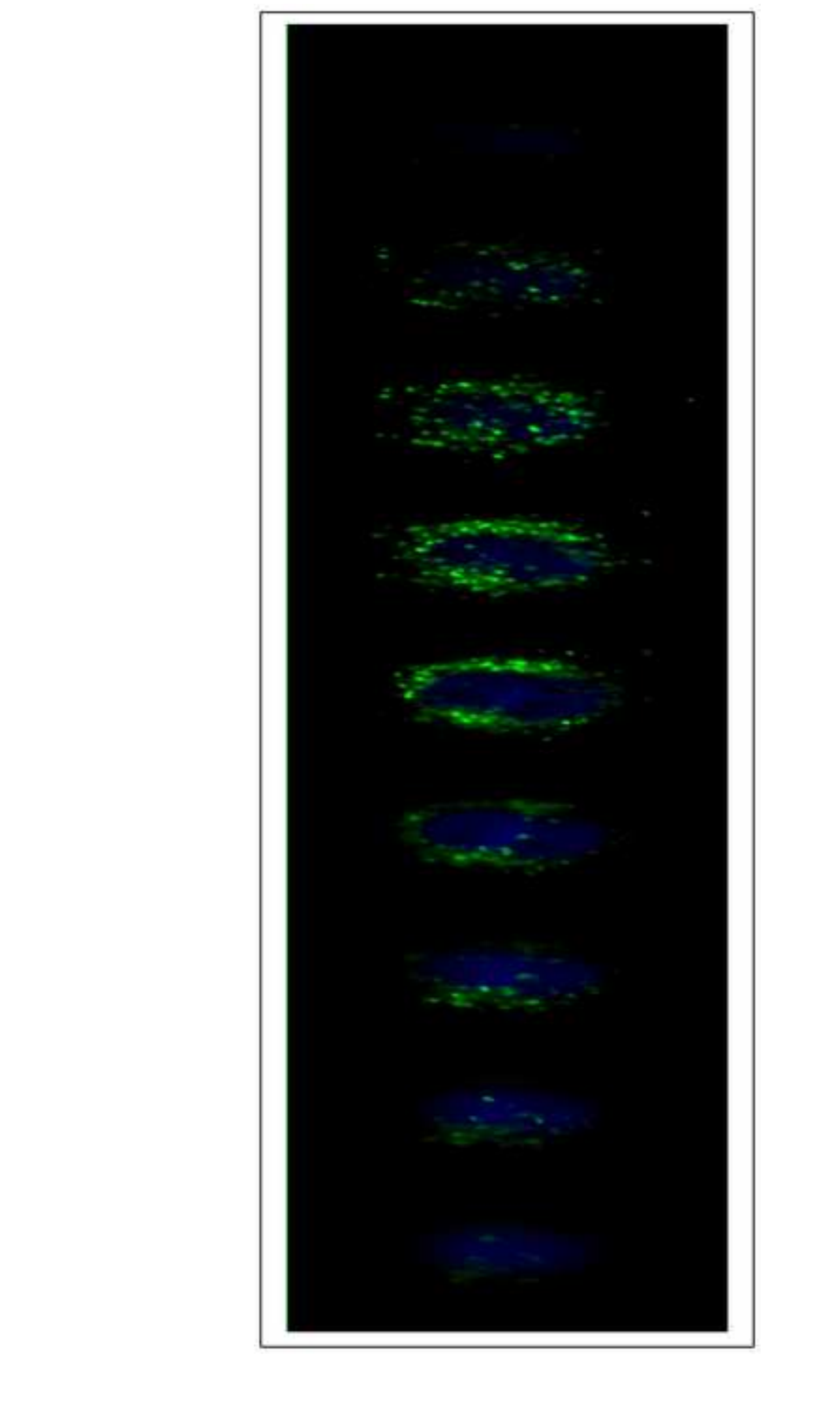


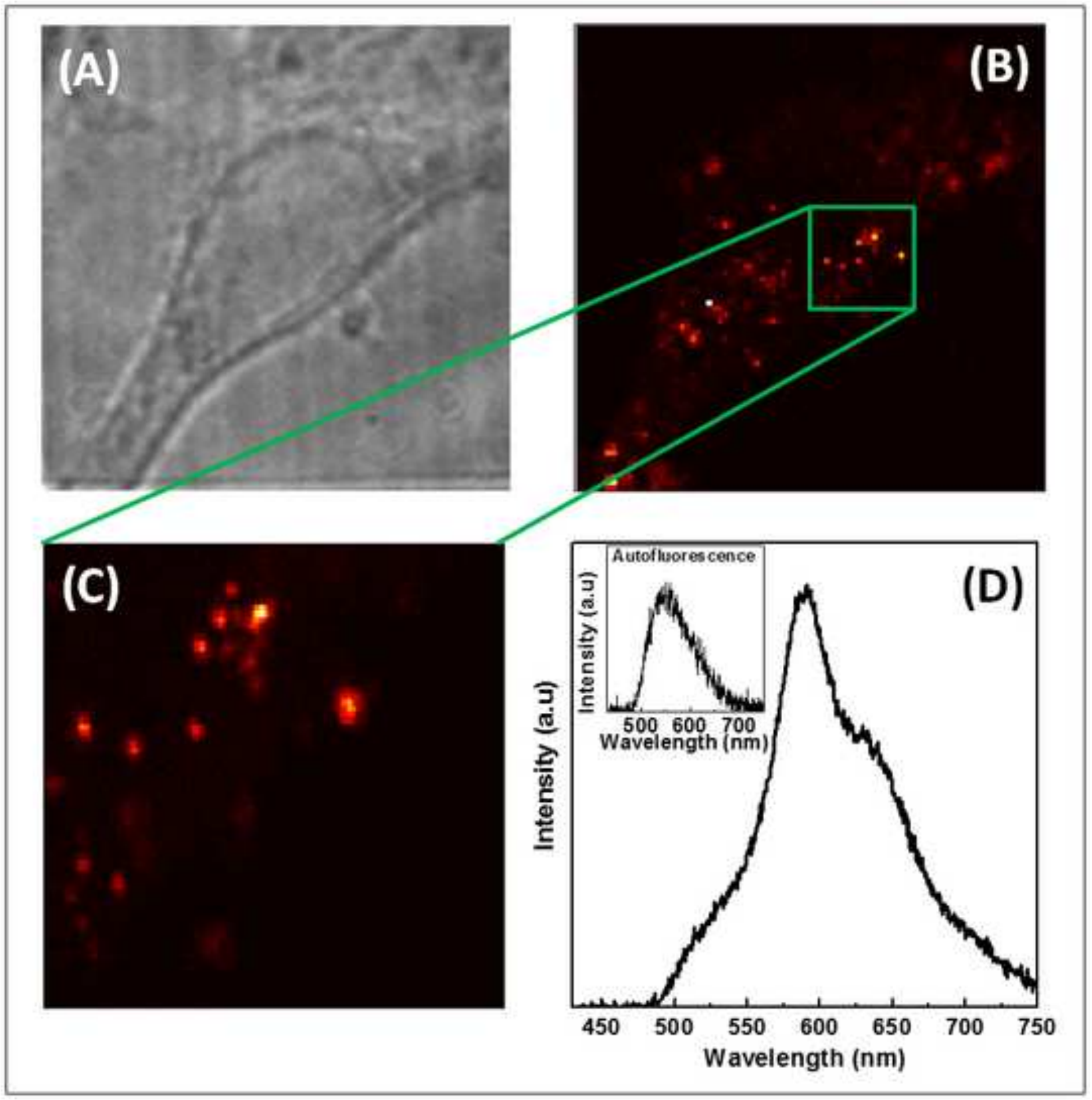


Figure 6

(A)

TE-71

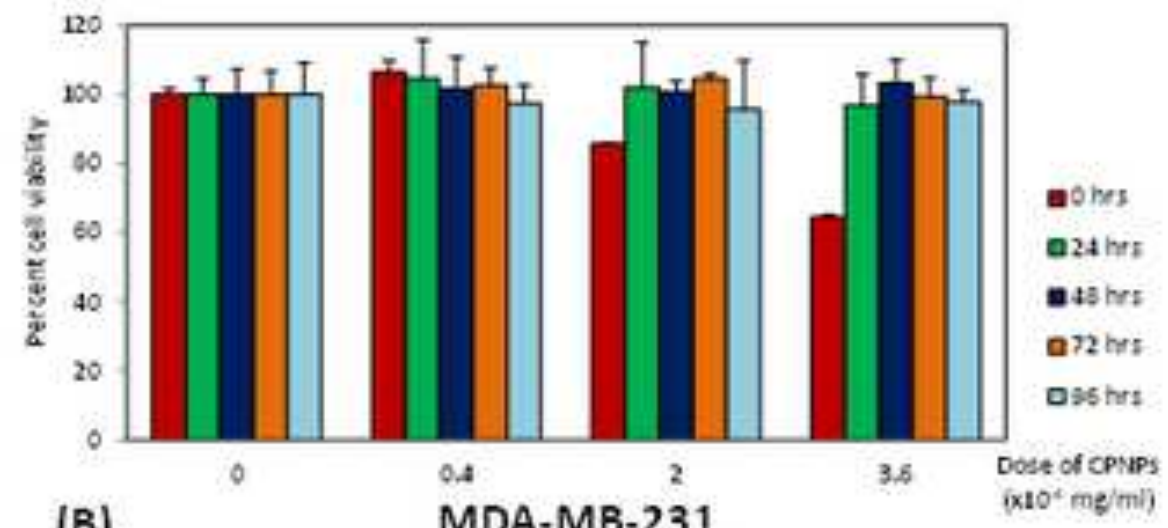

(B)

MDA-MB-231

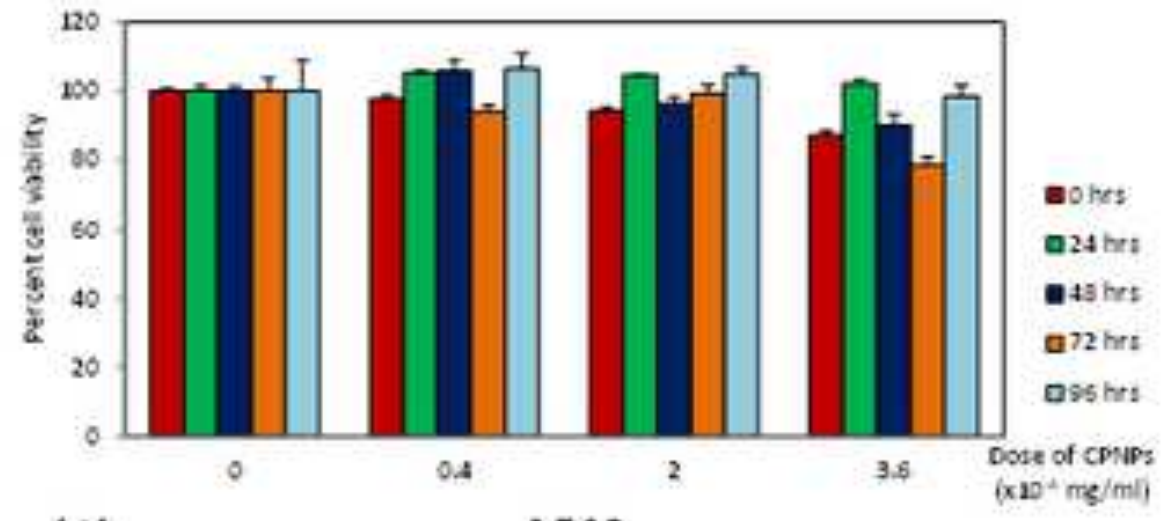

(c)

A549
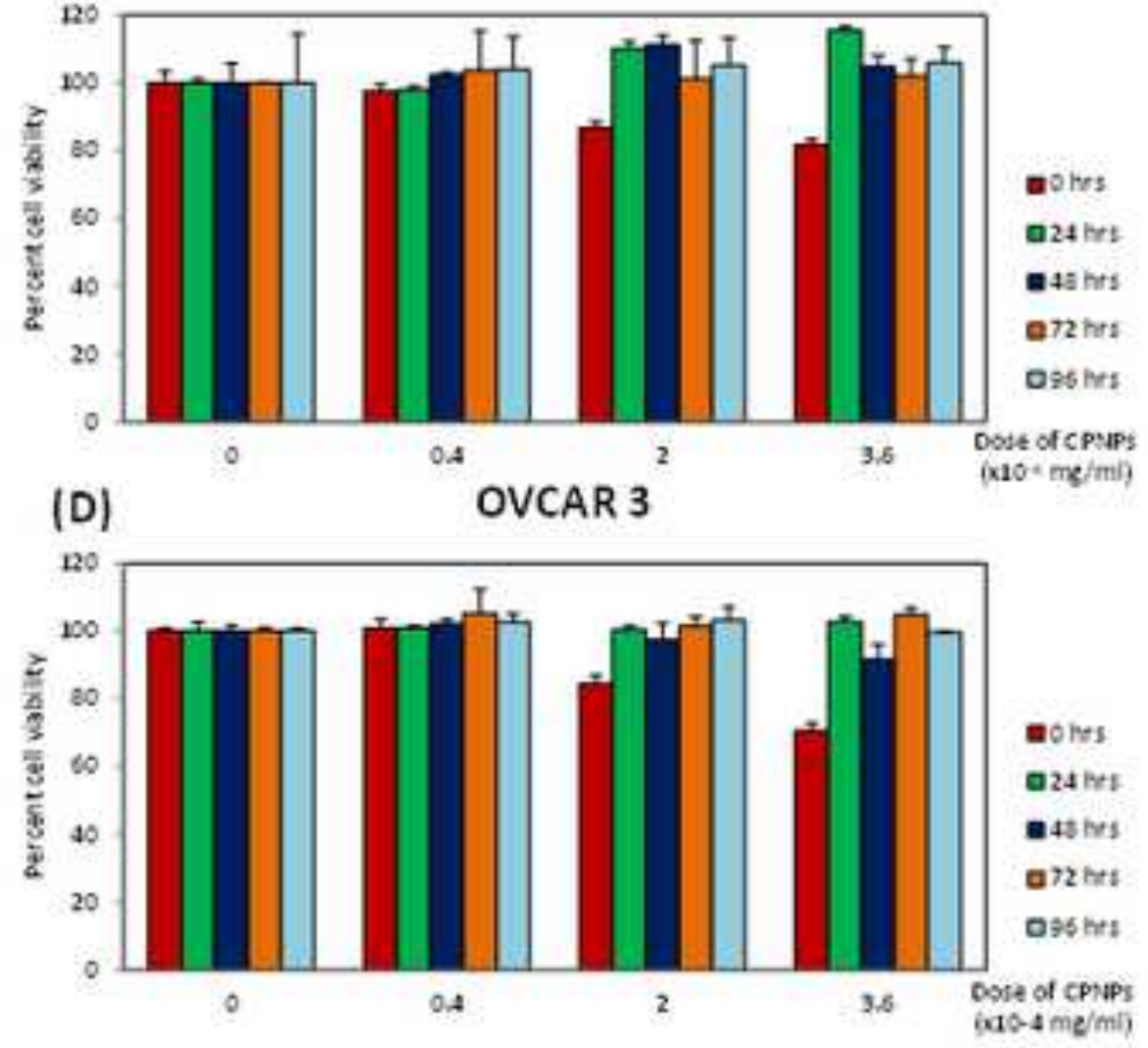


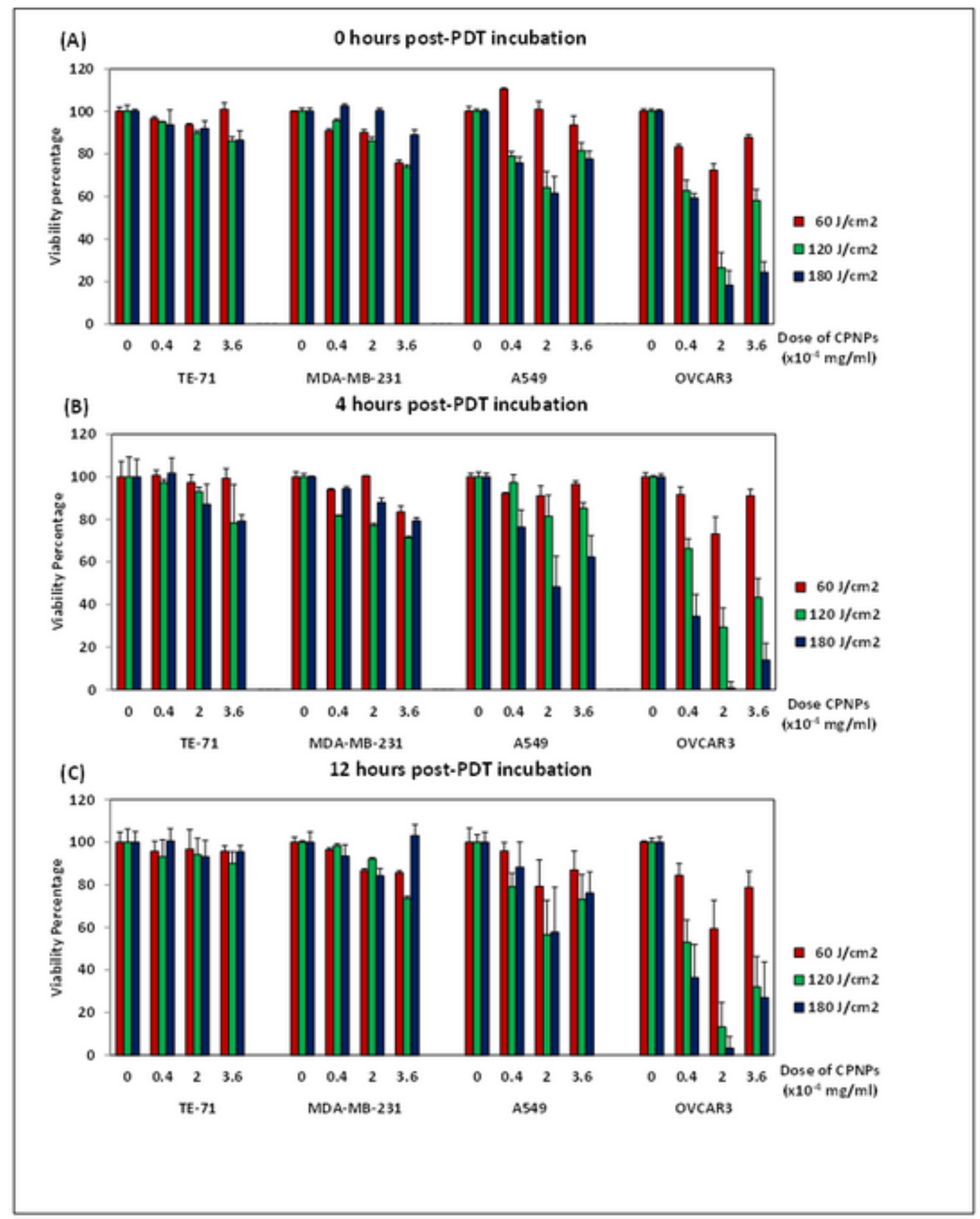




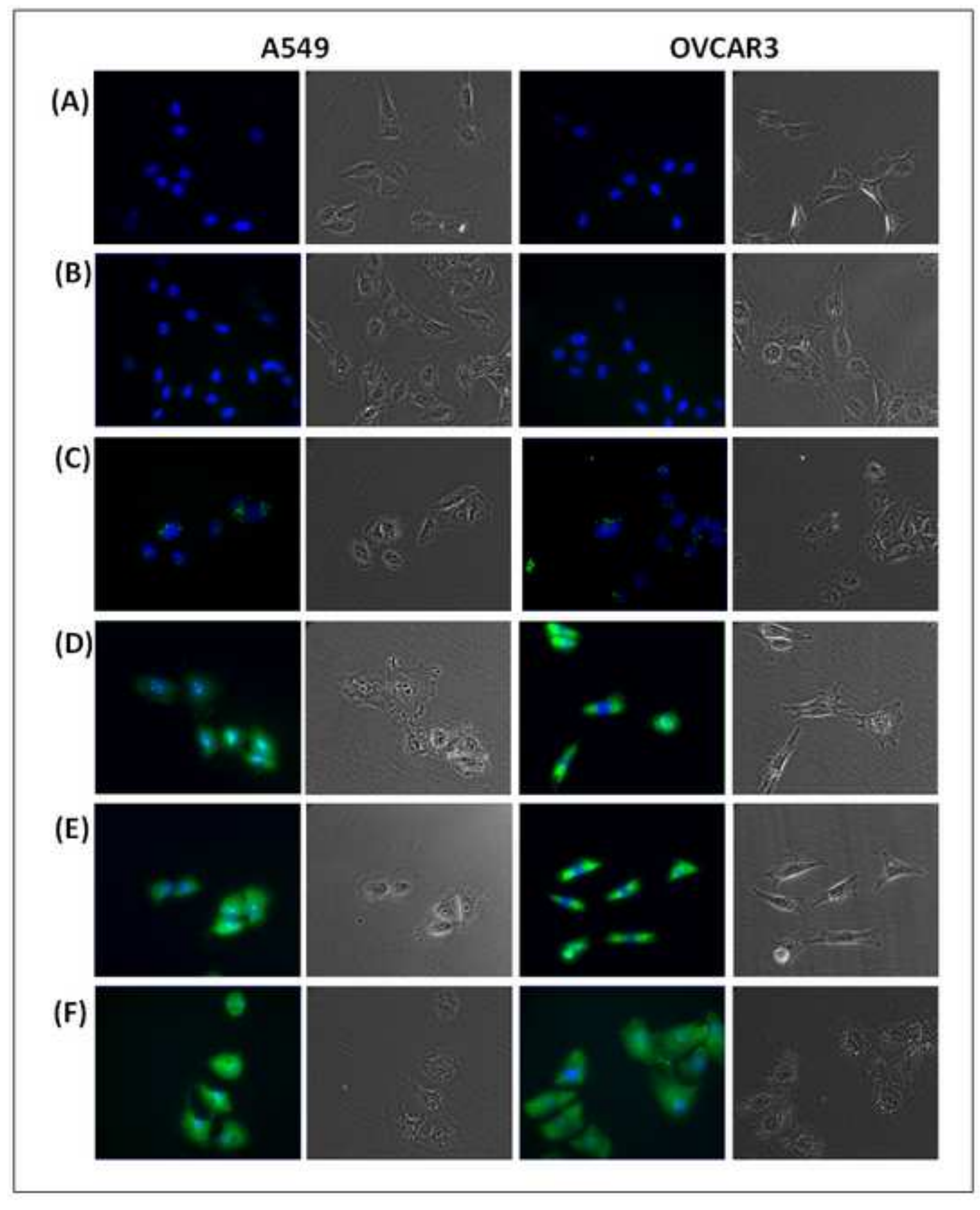

8

